\title{
A Validated Stability-indicating Liquid Chromatographic Method for Determination of Cabazitaxel-A Novel Microtubule Inhibitor
}

\section{Mathrusri Annapurna Mukthinuthalapati ${ }^{1 *}$, Venkatesh Bukkapatnam ${ }^{1}$ and Naga Supriya Grandhi ${ }^{2}$}

${ }^{1}$ Department of Pharmaceutical Analysis \& Quality Assurance, GITAM Institute of Pharmacy, GITAM University, Visakhapatnam, India ${ }^{2}$ Roland Institute of Pharmaceutical Sciences, Berhampur, Orissa

\begin{abstract}
Cabazitaxel is used to treat advanced prostate cancer. Cabazitaxel is a semi-synthetic derivative of the natural taxoid 10-deacetylbaccatin III with potential antineoplastic activity. Cabazitaxel is also known as XRP6258, a semisynthetic taxane from a single diastereoisomer of 10-deacetyl baccatin III derived from the needles of various Taxus species. A stability-indicating high performance liquid chromatographic technique was developed for the determination of Cabazitaxel in bulk and pharmaceutical formulations. Chromatographic separation was performed on Shimadzu Model CBM-20A/20 Alite, using Zorbax SB-C18 column (150 mm×4.6 mm i.d., $3.5 \mu \mathrm{m}$ particle size) with a mixture of $0.1 \%$ ortho phosphoric acid and methanol $(20: 80, \mathrm{v} / \mathrm{v})$ as mobile phase with a flow rate of $1.0 \mathrm{ml} /$ min. Cabazitaxel was subjected to stress conditions (acidic, alkaline, oxidation photolytic and thermal degradations and the method were validated as per ICH guidelines.
\end{abstract}

Keywords: Cabazitaxel; RP-HPLC; Stability-indicating; ICH

\section{Introduction}

Abazitaxel is used to treat advanced prostate cancer that is no longer responding to hormone therapy. It is also being studied for use against other kinds of cancer. It interferes with microtubules, which are part of the internal structure that cells need when they are dividing. This leads to cell death. Because cancer cells divide faster than normal cells, they are more likely than normal cells to be affected by this drug. Cabazitaxel is a semi-synthetic derivative of a natural taxoid used for the treatment of hormone-refractory prostate cancer [1]. Unlike other taxane compounds, this agent is a poor substrate for the membraneassociated, multidrug resistance (MDR), P-glycoprotein (P-gp) efflux pump and may be useful for treating multidrug-resistant tumors. Cabazitaxel binds to and stabilizes tubulin, resulting in the inhibition of microtubule depolymerization and cell division, cell cycle arrest in the $\mathrm{G} 2 / \mathrm{M}$ phase, and the inhibition of tumor cell proliferation.

Cabazitaxel has been approved in the US by the Food and Drug Administration (FDA) [2] in June 2010 and in Europe by the European Medicines Agency (EMA) in January 2011 in combination with prednisone for the treatment of patients with castration resistant metastatic prostate cancer whose disease progresses after docetaxel treatment [3], based on the results of the TROPIC trail investigating Cabazitaxel plus prednisone versus mitoxantrone plus prednisone following docetaxel failure [4]. Cabazitaxel chemically known as (2aR,4S,4aS,6R,9S,11S,12S,12aR,12bS-12bS)-12b-acetoxy9-(((2R, 3S)- 3-((tert-butoxycarbonyl) amino)-2-hydroxy-3-phenyl propanoyl) oxy)-11-hydroxy-4,6-dimethoxy 4a,8,13,13-tetramethyl5-oxo-2a,3,4,4a, 5, 6,9,10,11,12,12a,12b-dodecahydro- $1 \mathrm{H}-7,11$ methanocyclodeca benzo [1,2-b] oxet-12-yl benzoate is chemotherapy drug with molecular formula $\mathrm{C}_{45} \mathrm{H}_{57} \mathrm{NO}_{14}$ and molecular weight 835.93 $\mathrm{g} / \mathrm{mol}$ (Figure 1) [5,6]. Cabazitaxel penetrates the blood-brain barrier. Cabazitaxel is currently being investigated in the setting of metastatic breast cancer progressing after taxane or anthracycline based chemotherapeutic regimens $[7,8]$.

Very few analytical methods have been reported for the determination of Cabazitaxel such as spectroscopic techniques [9], HPLC [10,11], LC-MS/MS [12-14] in biological fluids. At present the authors have proposed a stability indicating RP-HPLC method for the determination of Cabazitaxel in presence of its degradation products.

\section{Experimental}

\section{Chemicals and reagents}

Cabazitaxel standard (purity 99\%) was obtained from Dr. Reddy's Laboratories Ltd. (Visakhapatnam, India). Methanol (HPLC grade),

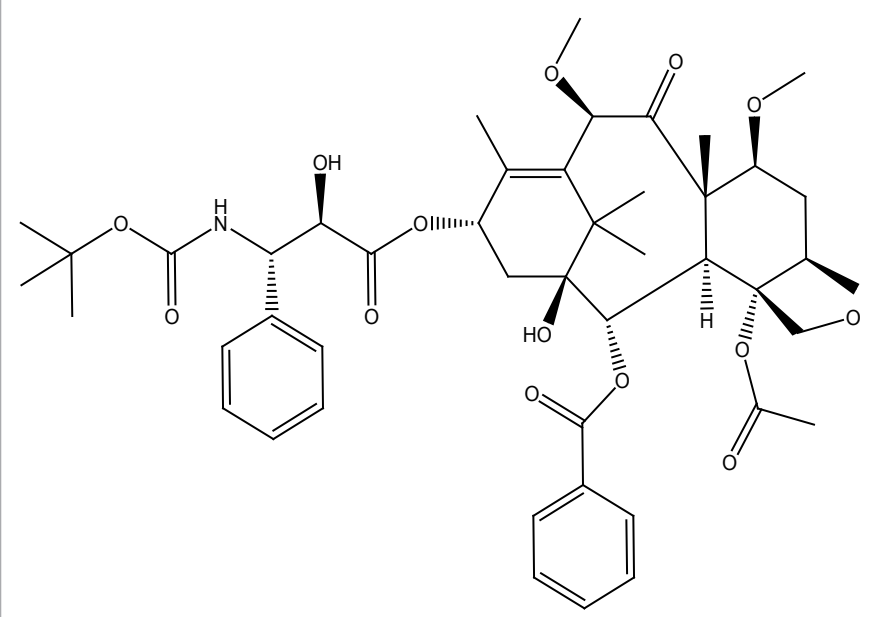

Figure 1: Chemical structure of Cabazitaxel.

*Corresponding author: Mathrusri Annapurna Mukthinuthalapati Department of Pharmaceutical Analysis \& Quality Assurance, GITAM Institute of Pharmacy, GITAM University, Visakhapatnam, India, E-mail: mathrusri2000@yahoo.com

Received June 23, 2014; Accepted July 28, 2014; Published August 06, 2014

Citation: Mathrusri Annapurna M, Venkatesh B, Naga Supriya G (2014) A Validated Stability-indicating Liquid Chromatographic Method for Determination of Cabazitaxel-A Novel Microtubule Inhibitor. J Bioequiv Availab 6: 134-138. doi:10.4172/jbb.1000193

Copyright: (c) 2014 Mukthinuthalapati MA. This is an open-access article distributed under the terms of the Creative Commons Attribution License, which permits unrestricted use, distribution, and reproduction in any medium, provided the original author and source are credited. 
Polysorbate 80, Ethanol (HPLC grade), Sodium hydroxide $(\mathrm{NaOH})$ and Hydrochloric acid $(\mathrm{HCl})$, orthophosphoric acid and Hydrogen peroxide $\left(\mathrm{H}_{2} \mathrm{O}_{2}\right)$ were purchased from Merck (India). All chemicals were of analytical grade and used as received.

Cabazitaxel is available as infusion with brand name Jevtana (Sanofi-Aventis, Malaysia) with label claim of $60 \mathrm{mg}$ of drug $(60 \mathrm{mg}$ cabazitaxel in $1.5 \mathrm{~mL}$ polysorbate 80 with diluent approximately 5.7 $\mathrm{mL}$ of $13 \%(\mathrm{w} / \mathrm{w})$ ethanol in water for injection).

\section{Instrumentation}

Chromatographic separation was achieved by using Zorbax SBC18 column (150 mm $\times 4.6 \mathrm{~mm}$ i.d., $3.5 \mu \mathrm{m}$ particle size) for HPLC system of Shimadzu Model CBM-20A/20 Alite, equipped with SPD $\mathrm{M} 20 \mathrm{~A}$ prominence photodiode array detector (maintained at $25^{\circ} \mathrm{C}$ ) and LC Solutions 1.25 software.

\section{Chromatographic conditions}

Isocratic elution was performed using $0.1 \%$ orthophosphoric acid: methanol $(20: 80, v / v)$ as mobile phase. The overall run time was 10 min. with flow rate $1.0 \mathrm{ml} / \mathrm{min}$ with UV detection at $210 \mathrm{~nm} .20 \mu \mathrm{L}$ of sample was injected into the HPLC system.

\section{Preparation of stock solution}

Cabazitaxel stock solution $(1000 \mu \mathrm{g} / \mathrm{ml})$ was prepared by weighing accurately $25 \mathrm{mg}$ of Cabazitaxel in a $25 \mathrm{ml}$ volumetric flask with mobile phase. Working standard solutions were prepared on daily basis from the stock solution with mobile phase and filtered through $0.45 \mu \mathrm{m}$ membrane filter prior to injection.

\section{Method validation}

The method was validated for system suitability, linearity, limit of quantitation (LOQ), limit of detection (LOD), precision, accuracy, selectivity and robustness [15].

Linearity test solutions for the assay method were prepared from a stock solution at different concentration levels $(0.1-200 \mu \mathrm{g} / \mathrm{ml})$ of the assay analyte concentration and $20 \mu \mathrm{L}$ of each solution was injected in to the HPLC system and the peak area of the chromatogram obtained was noted. The calibration curve was plotted by taking the concentration on the $\mathrm{x}$-axis and the corresponding peak area on the $\mathrm{y}$-axis. The data was treated with linear regression analysis method.

The limit of quantification and limit of detection were based on the standard deviation of the response and the slope of the constructed calibration curve ( $\mathrm{n}=3)$, as described in ICH guidelines Q2 (R1) [15].

Precision was evaluated at three concentration levels $(20,50$ and $100 \mu \mathrm{g} / \mathrm{ml}$ ) against the qualified reference standard. The intra-day precision study was carried out by doing 3 independent assays for each concentration of Cabazitaxel and the mean as well as the \% RSD were calculated for each concentration. The inter-day precision study was performed on three different days i.e. day 1 , day 2 and day 3 at three different concentration levels $(20,50$ and $100 \mu \mathrm{g} / \mathrm{ml})$ and each value is the average of three determinations. The $\%$ RSD of three obtained assay values on three different days was calculated.

Standard addition and recovery experiments were conducted to determine the accuracy of the method. The study was carried out in triplicate at three different levels $(80,100$ and $120 \%)$ and the percentage recovery was calculated. The accuracy study was performed by adding known amount of the standard $(8,10$ and $12 \mu \mathrm{g} / \mathrm{ml})$ to the samples which was prepared in our laboratory using the excipients. The study was carried out in triplicates and the percentage recoveries were calculated according to table 3 .

The robustness of the assay method was established by introducing small changes in the HPLC conditions which included wavelength (208 and $212 \mathrm{~nm}$ ), percentage of methanol in the mobile phase (78 and $82 \%)$ and flow rate $(0.9$ and $1.1 \mathrm{ml} / \mathrm{min})$ and each value (Table 4$)$ is the average of three determinations. Robustness of the method was studied for $100 \mu \mathrm{g} / \mathrm{ml}$ of Cabazitaxel.

As the marketed formulations were not available in India the drug was mixed with some of the common excipients used in the laboratory and extracted with the mobile phase. The percentage recovery was calculated from the calibration curve.

\section{Forced degradation studies}

Forced degradation studies were performed to evaluate the stability indicating properties and specificity of the method [16]. All solutions for stress studies were prepared at an initial concentration of $1 \mathrm{mg} / \mathrm{ml}$ of Cabazitaxel and refluxed for $30 \mathrm{~min}$ at $60^{\circ} \mathrm{C}$ and then diluted with mobile phase. $1.0 \mathrm{mg} / \mathrm{ml}$ Cabazitaxel solution was exposed to acidic degradation with $0.1 \mathrm{M} \mathrm{HCl}$ for $20 \mathrm{~min}$ at $60^{\circ} \mathrm{C}$ the stressed sample was cooled, neutralized and diluted with mobile phase. Similarly stress studies were conducted in alkaline conditions with $0.01 \mathrm{M} \mathrm{NaOH}$ at $60^{\circ} \mathrm{C}$ for $20 \mathrm{~min}$. and neutralized after cooling with proper dilution with mobile phase. Oxidative stress studies were performed using $30 \% \mathrm{H}_{2} \mathrm{O}_{2}$ and thermal stress studies were conducted in thermostat at $60^{\circ} \mathrm{C}$ for 20 min. $20 \mu \mathrm{L}$ solution of each of these solutions which were exposed to forced degradation studies were injected in to the HPLC system and the chromatograms were recorded from which the percentage recovery as well as the degradants were studied.

\section{Results and Discussion}

\section{Method optimization}

Initially the stressed samples were analyzed using a mixture of $0.1 \%$ ortho phosphoric acid: methanol $(45: 55, \mathrm{v} / \mathrm{v})$ with a flow rate of 1.0 $\mathrm{ml} / \mathrm{min}$ in which the peak shape was not symmetrical. Then the mobile phase composition was slightly modified with $0.1 \%$ ortho phosphoric acid: methanol $(20: 80, \mathrm{v} / \mathrm{v})$ where a sharp peak was eluted at $4.241 \pm$ $0.02 \mathrm{~min}$ without tailing (UV detection $210 \mathrm{~nm}$ ) which was taken as the best chromatographic response for the entire study. The typical chromatogram of the blank as well as the drug solution was shown in Figure 3 respectively. The performance characteristics of the present stability indicating liquid chromatographic method was compared and discussed with the previously published methods in Table 1.

\section{Method validation}

Cabazitaxel has shown linearity $0.1-200 \mu \mathrm{g} / \mathrm{ml}$ (Table 2 ) (\% RSD 0.11-0.54) with linear regression equation

$$
\mathrm{y}=21017 \mathrm{x}+3853.9\left(\mathrm{r}^{2}=0.9999\right)
$$

The LOQ was found to be $0.0967 \mu \mathrm{g} / \mathrm{ml}$ and the LOD was found to be $0.0319 \mu \mathrm{g} / \mathrm{ml}$ (Figure 2).

The \% RSD range was obtained as $0.23-1.43$ and $0.21-0.51$ for intraday and inter-day precision studies respectively and $98.95-99.43 \%$ of recovery was observed in the accuracy studies with \% RSD 0.28-0.60 $(<2.0 \%)$ (Table 3) indicating that the method is precise and accurate.

The robustness of an analytical procedure refers to its ability to remain unaffected by small and deliberate variations in method parameters and provides an indication of its reliability for routine 
Citation: Mathrusri Annapurna M, Venkatesh B, Naga Supriya G (2014) A Validated Stability-indicating Liquid Chromatographic Method for Determination of Cabazitaxel-A Novel Microtubule Inhibitor. J Bioequiv Availab 6: 134-138. doi:10.4172/jbb.1000193

\begin{tabular}{|c|c|c|c|c|}
\hline Mobile phase/Reagent & $\lambda(\mathrm{nm})$ & Linearity $(\mu \mathrm{g} / \mathrm{ml})$ & Remarks & Reference \\
\hline Phosphate buffer: Acetonitrile (30:70, v/v) & 230 & $0.1-150$ & HPLC & [10] \\
\hline Sodium acetate buffer: Acetonitrile $(30: 70, \mathrm{v} / \mathrm{v})$ & 234 & $0.1-250$ & HPLC & [11] \\
\hline $\begin{array}{l}\text { Ammonium hydroxide and methanol } \\
(83: 17, \mathrm{v} / \mathrm{v})(\mathrm{pH} 3 \pm 0.1)\end{array}$ & 275 & $2-20$ & LC-MS & [12] \\
\hline Acetonitrile: Ammonium acetate $(80: 20, \mathrm{v} / \mathrm{v})$ & 236 & $2.49-99.60$ & (LC-MS/MS) (dried blood spots) & [13] \\
\hline Acetonitrile: Ammonium formate (gradient) & 362 & $(10-100) 10^{3}$ & (LC-MS) Human plasma & [14] \\
\hline o-phosphoric acid : Methanol (20:80, v/v) & 210 & $0.1-200$ & $\begin{array}{l}\text { Stability indicating HPLC } \\
\text { (PDA detector) }\end{array}$ & Present work \\
\hline
\end{tabular}

Table 1: Comparison of the previously published liquid chromatographic methods with the present method.

\begin{tabular}{|c|c|c|}
\hline Conc. $(\boldsymbol{\mu g} / \mathbf{m l})$ & *Mean peak area \pm SD & * \\
\hline 0.1 & $2552 \pm 587$ & 0.23 \\
\hline 1 & $111635 \pm 112.80$ & 0.31 \\
\hline 5 & $207597 \pm 871.91$ & 0.11 \\
\hline 10 & $410587 \pm 1149.64$ & 0.42 \\
\hline 50 & $1085699 \pm 4885.65$ & 0.28 \\
\hline 100 & $2109177 \pm 4218.35$ & 0.45 \\
\hline 150 & $3156873 \pm 9786.31$ & 0.20 \\
\hline 200 & $4198887 \pm 22673.99$ \\
\hline
\end{tabular}

*Mean of three replicates

Table 2: Linearity of Cabazitaxel.

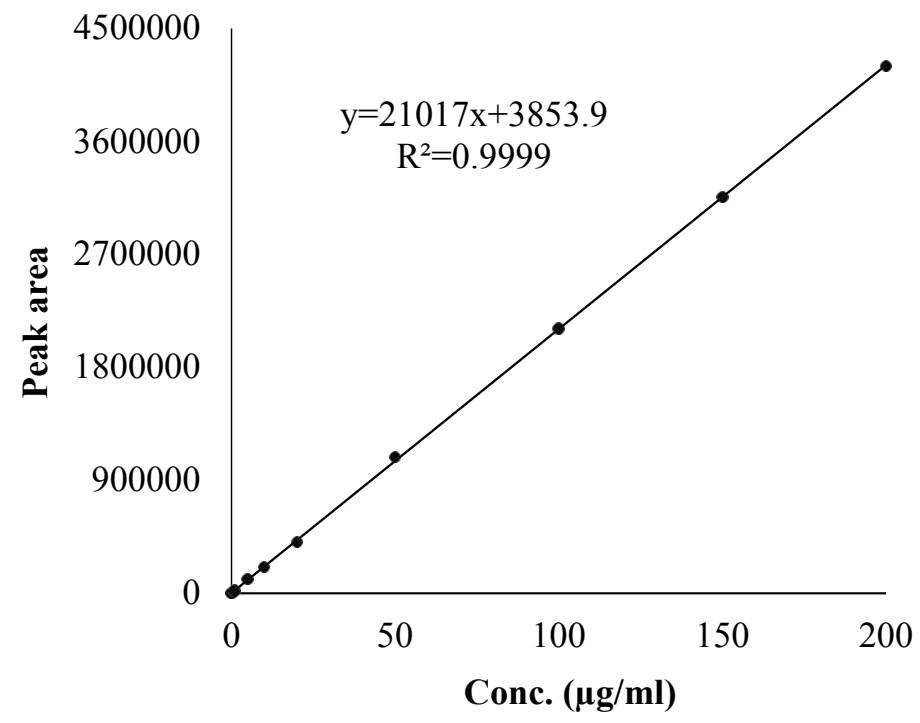

Figure 2: Calibration curve of Cabazitaxel.

analysis. The results obtained (Table 4) from assay of the test solutions were not affected by varying the conditions and were in accordance with the results for original conditions. The \% RSD was less than $2.0 \%$ (0.19-1.66) indicating that the proposed method is robust.

As the marketed formulation was not available the drug was mixed with different excipients available in the laboratory and then extracted using the mobile phase. The proposed method was applied to the laboratory prepared formulation and the percentage recovery was calculated as 97.84 .

\section{Forced degradation studies}

The stability indicating capability of the method was established from the separation of Cabazitaxel peak from the degraded samples. The typical chromatograms obtained from the forced degradation studies were shown in Figure 3. Cabazitaxel has shown 19.48\% degradation with degradant at 1.736 min during acidic stress indicating that the drug is sensitive towards acidic environment. The amino group present in the drug structure may be highly responsible for this degradation. Cabazitaxel has undergone complete decomposition with degradants $1.667 \mathrm{~min}, 1.992 \mathrm{~min}$ and $2.571 \mathrm{~min}$ at during alkali stress indicating that the drug is very much sensitive towards alkaline condition. In other degradations the drug has undergone decomposition slightly $(<15.0 \%)$. Decomposition was seen on exposure of Cabazitaxel solution to acidic (19.48\%), alkaline $(99.72 \%)$, oxidative $(0.17 \%)$ thermal $(1.03 \%)$ and photolytic (3.02\%) conditions (Table 5). It is concluded that Cabazitaxel is very much sensitive towards alkaline conditions.

The present stability-indicating method for the determination of 
Citation: Mathrusri Annapurna M, Venkatesh B, Naga Supriya G (2014) A Validated Stability-indicating Liquid Chromatographic Method for Determination of Cabazitaxel-A Novel Microtubule Inhibitor. J Bioequiv Availab 6: 134-138. doi:10.4172/jbb.1000193

\begin{tabular}{|c|c|c|c|c|}
\hline \multirow{2}{*}{ Conc. $(\mu \mathrm{g} / \mathrm{ml})$} & \multicolumn{2}{|c|}{ Intra-day precision } & \multicolumn{2}{|c|}{ Inter-day precision } \\
\hline & \multicolumn{2}{|c|}{ *Mean peak area \pm SD (\% RSD) } & \multicolumn{2}{|c|}{${ }^{*}$ Mean peak area \pm SD (\% RSD) } \\
\hline 20 & \multicolumn{2}{|c|}{$410508.33 \pm 961.20(0.23)$} & \multicolumn{2}{|c|}{$410331.33 \pm 867.24(0.21)$} \\
\hline 50 & \multicolumn{2}{|c|}{$1069037.33 \pm 15310.37(1.43)$} & \multicolumn{2}{|c|}{$1084725.33 \pm 5525.22(0.51)$} \\
\hline 100 & \multicolumn{2}{|c|}{$2114961.00 \pm 9778.37(0.46)$} & \multicolumn{2}{|c|}{$2110788.33 \pm 5377.64(0.25)$} \\
\hline \multicolumn{5}{|c|}{ Accuracy } \\
\hline Spiked conc. $(\mu \mathrm{g} / \mathrm{ml})$ & Total conc. $(\mu \mathrm{g} / \mathrm{ml})$ & Mean peak area \pm SD ( $\%$ RSD) & Drug Found $(\mu \mathrm{g} / \mathrm{ml})$ & $\%$ Recovery* \\
\hline $8(80 \%)$ & 18 & $378301.00 \pm 1042.36(0.28)$ & 17.82 & 98.98 \\
\hline $10(100 \%)$ & 20 & $421803.00 \pm 1587.67(0.38)$ & 19.89 & 99.43 \\
\hline $12(120 \%)$ & 22 & $461385.33 \pm 2765.64(0.60)$ & 21.77 & 98.95 \\
\hline
\end{tabular}

*Mean of three replicates

Table 3: Precision and accuracy studies of Cabazitaxel.

\begin{tabular}{|c|c|c|c|}
\hline Parameter & Condition & ${ }^{*}$ Mean peak area \pm SD (\% RSD) & *Assay (\%) \\
\hline $\begin{array}{c}\text { Flow rate } \\
( \pm 0.1 \mathrm{ml} / \mathrm{min})\end{array}$ & $\begin{array}{l}0.9 \\
1.0 \\
1.1\end{array}$ & $2102325.00 \pm 14560.41(0.69)$ & 99.86 \\
\hline $\begin{array}{l}\text { Detection } \\
\text { wavelength } \\
( \pm 2 \mathrm{~nm})\end{array}$ & $\begin{array}{l}208 \\
210 \\
212\end{array}$ & $2103174.33 \pm 3932.91(0.19)$ & 99.90 \\
\hline $\begin{array}{l}\text { Mobile phase } \\
\text { composition } \\
( \pm 2 \%, v / v)\end{array}$ & $\begin{array}{l}18: 82 \\
20: 80 \\
22: 78\end{array}$ & $2093672.33 \pm 34806.61(1.66)$ & 99.45 \\
\hline
\end{tabular}

*Mean of three replicates

Table 4: Robustness study of Cabazitaxel.

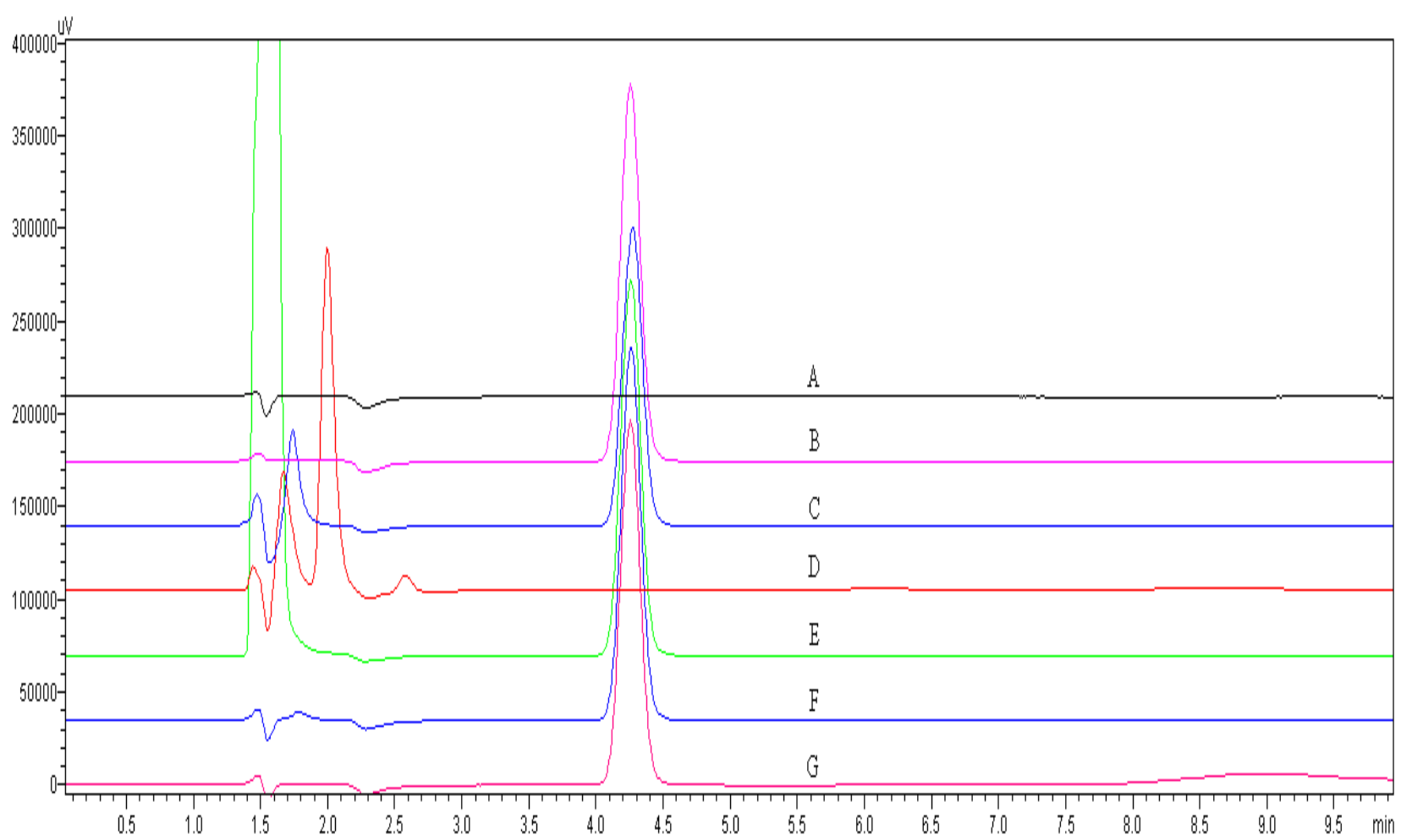

Figure 3: Typical chromatograms of blank [A], Cabazitaxel $(100 \mu \mathrm{g} / \mathrm{ml})[B]$, acidic [C], alkaline [D], oxidative [E], thermal [F] and photolytic [G] degradations

Cabazitaxel in pharmaceutical formulations is specific because the drug peak was well separated even in the presence of degradation products. The system suitability parameters for the Cabazitaxel peak shows that the theoretical plates were more than 2000 and the tailing factor was less than 2 (or $<1.5-2.0)$ (Table 5).

\section{Conclusion}

The proposed stability-indicating liquid chromatographic method for the determination of cabazitaxel is economical as acetonitrile was replaced with methanol and the method can be applied for the assay of pharmaceutical dosage forms. Cabazitaxel is very much sensitive 
Citation: Mathrusri Annapurna M, Venkatesh B, Naga Supriya G (2014) A Validated Stability-indicating Liquid Chromatographic Method for Determination of Cabazitaxel-A Novel Microtubule Inhibitor. J Bioequiv Availab 6: 134-138. doi:10.4172/jbb.1000193

\begin{tabular}{|c|c|c|c|c|c|}
\hline Stress Condition & *Mean peak area & *Drug recovered (\%) & *Drug decomposed (\%) & Theoretical plates & Tailing factor \\
\hline Standard (Untreated) & 2109177 & 100 & - & 3517.939 \\
\hline Acidic & 1698271 & 80.52 & 19.48 & 3392.511 \\
\hline Alkaline & 5807 & 0.28 & 99.72 & - \\
\hline Oxidative & 2105689 & 99.83 & 0.17 & 3415.160 \\
\hline Thermal & 2087474 & 98.97 & 1.03 & 3 \\
\hline Photolytic & 2045504 & 96.98 & 3.02 & 3521.359 \\
\hline
\end{tabular}

*Mean of three replicates

Table 5: Forced degradation studies of Cabazitaxel.

towards the alkaline conditions and it can be very easily undergoes decomposition.

\section{Acknowledgements}

The authors are grateful to University Grants Commission, New Delhi for their financial support and to M/s GITAM University, Visakhapatnam for providing the research facilities.

\section{References}

1. O'Neil MJ (2006) The Merck Index, Merck Research Laboratories, Whitehouse Station, NJ.

2. Oudard S (2011) TROPIC: Phase III trial of cabazitaxel for the treatment of metastatic castration-resistant prostate cancer. See comment in PubMed Commons below Future Oncol 7: 497-506

3. (2011) Assessment Report for Jevtana (Cabazitaxel). Procedure No.: EMEA $\mathrm{H} / \mathrm{C} / 002018$, European Medicines Agency, London.

4. de Bono JS, Oudard S, Ozguroglu M, Hansen S, Machiels JP, et al. (2010) Prednisone plus cabazitaxel or mitoxantrone for metastatic castration-resistant prostate cancer progressing after docetaxel treatment: a randomised openlabel trial. See comment in PubMed Commons below Lancet 376: 1147-1154.

5. (2010) Jevtana (Cabazitaxel) Injection approved by U.S. FDA after priority review (Press release). sanofi-aventis.

6. Cheetham P, Petrylak DP (2013) Tubulin-targeted agents including docetaxe and cabazitaxel. See comment in PubMed Commons below Cancer J 19: 5965.

7. Pivot X, Koralewski P, Hidalgo JL, Chan A, Goncalves A, et al. (2008) A multicenter phase II study of XRP6258 administered as a 1-h i.v. infusion every 3 weeks in taxane-resistant metastatic breast cancer patients. Ann Oncol 19: $1547-1552$.

8. Villanueva C, Awada A, Campone M, Machiels JP, Besse T, et al. (2011) A multicentre dose-escalating study of Cabazitaxel (xrp6258) in combination with capecitabine in patients with metastatic breast cancer progressing after anthracycline and taxane treatment: A phase I/II study. Eur J Cancer 47: 10371045.

9. Gudisa Kishore (2012) New spectrophotometric methods for the quantitative estimation of Cabazitaxel in formulations. International Journal of Research and Reviews in Pharmacy and Applied science 2: 950-958.

10. Mathrusri Annapurna M, Pramadvara K, Venkatesh B, Sowjanya G (2013) Stability-indicating RP-HPLC method for the determination of Cabazitaxel. Indo American Journal of Pharmaceutical Research 3: 9262-9269.

11. Mathrusri Annapurna M, Venkatesh B, Pramadvara K, Hemchand S (2014) Development and validation of a stability-indicating liquid chromatographic method for the assay of Cabazitaxel. Chemical science transactions 3: 854860.

12. Kort A, Hillebrand MJX, Cirkel GA, Voest EE, Schinkel AH, et al. (2013) Quantification of Cabazitaxel, its metabolite docetaxel and the determination of the demethylated metabolites RPR112698 and RPR123142 as docetaxe equivalents in human plasma by liquid chromatography tandem mass spectrometry. J Chromatogr B Analyt Technol Biomed Life Sci 925: 117-123.

13. Jagannath Patro V, Nageshwara Rao R, Tripathy NK (2012) LC-MS/MS determintion of Cabazitaxel in rat whole blood on dry blood Spots. Open Access Scientific Reports 1: 1-4.

14. Peter de Bruijn, Anne-Joy M de Graan, Annemieke Nieuweboer, Ron Mathijssen HJ, Mei-Ho Lam, et al. (2012) Quantification of Cabazitaxel in human plasma by liquid chromatography/ triple-quadrupole mass spectrometry: A practical solution for non-specific binding. J Pharm Biomed Anal 59: 117-122.

15. (2005) ICH validation of analytical procedures: text and methodology Q2 (R1), International Conference on Harmonization.

16. Food and Drug Administration, HHS (2003) International Conference on Harmonisation; Stability Data Package for Registration Applications in Climatic Zones III and IV; Stability Testing of New Drug Substances and Products: availability. Notice. See comment in PubMed Commons below Fed Regist 68 65717-65718 